\title{
GIS approach to estimate windbreak crop yield effects in Kansas-Nebraska
}

\author{
Raúl J. Osorio 1 - Charles J. Barden · Ignacio A. Ciampitti
}

Received: 10 February 2018/ Accepted: 27 June 2018/Published online: 25 July 2018

(C) The Author(s) 2018

\begin{abstract}
Windbreaks were originally promoted across the U.S. Great Plains to reduce wind erosion. A review paper published nearly 30 years ago showed yield increases for a variety of crops associated with windbreaks. However, with the widespread use of notill cropping systems and advanced crop genetics, the question is "Do windbreaks still provide a yield benefit?" This study compared data from protected and unprotected fields over multiple years across Kansas and Nebraska looking at relative soybean (Glycine max L.) and winter wheat (Triticum aestivum L.) yield differences. Farmer's pre-existing georeferenced data, generated by automated combine yield monitors, were analyzed with ArcGIS 10.3.1 to visualize windbreak interaction with crop yield. Statistics were conducted to determine if the yield in protected areas of the field was significantly different from the yield in unprotected areas. Also, yield loss was estimated from the windbreak footprint to assess if yield increases were enough to compensate for the
\end{abstract}

R. J. Osorio $(\bowtie) \cdot$ C. J. Barden

Department of Horticulture and Natural Resources,

College of Agriculture, Kansas State University, 2021

Throckmorton Hall, 1712 Claflin Rd, Manhattan,

KS 66506, USA

e-mail: raulosoriomorillo@yahoo.es

I. A. Ciampitti

Department of Agronomy, College of Agriculture, Kansas State University, 2021 Throckmorton Hall, 1712 Claflin Rd, Manhattan, KS 66506, USA area taken out of crop production. Results showed: soybeans (57 crop/years) presented the most positive response to windbreak effect with significant yield increases $46 \%$ of the time, with a $16 \%\left(283 \mathrm{~kg} \mathrm{ha}^{-1}\right)$ average yield increase. Wheat (44 crop/years) yield increases were significant $30 \%$ of the time, with a $10 \%$ $\left(319 \mathrm{~kg} \mathrm{ha}^{-1}\right)$ average yield increase. Narrow windbreaks (1-2 tree rows, average width of $13 \mathrm{~m}$ ) and those on the north edge of fields resulted in yield increases that compensated for the footprint of the windbreak more often $(71 \%)$ than wider windbreaks on the south edges of fields (38\%).

Keywords Windbreak effects - Soybeans - Wheat . Shelterbelts · Agroforestry

\section{Introduction}

Windbreaks were widely promoted and established across the Great Plains region of the U.S. to reduce wind erosion, following the 1930s Dust Bowl that damaged the U.S. and Canadian agricultural prairies (Hansen and Libecap 2004). The U.S. Congress financed the Prairie States Forestry Project, through the U.S. Forest Service (Droze 1977). A total of 250 million trees were planted in 30,000 windbreaks with a total length of $29,900 \mathrm{~km}$ from Texas to Canada, by 1942, in a 160-km wide zone (Droze 1977; Croker 
1991). Field windbreaks are considered to be part of a sustainable agricultural system consisting of single or multiple lines of trees and shrubs planted along the edge of agriculture lands mainly to reduce the wind erosion and provide protection to field crops (Brandle et al. 2004).

In Kansas, the most recent windbreak assessment was conducted by the Great Plains Initiative in 2008 and 2009. Moser et al. (2008) using GIS across multicounty regions, reported an estimate of 289,577 windbreaks with a length of $69,900 \mathrm{~km}$ protecting 0.49 million hectares of land. Ghimire et al. (2014) estimated that $44 \%$ of Kansas windbreaks were in fair to poor condition. In this research, only windbreaks in good conditions were considered, with most of the windbreaks (87\%) being located in Kansas.

The first and main parameter to consider before planting a windbreak is orientation. Windbreaks are effective when they are located perpendicular to the prevailing wind direction (Tamang et al. 2015). Careful species selection depending on the soil-site conditions and designing the windbreak to reduce its width, maximizes crop yield benefits (Kort 1988). Also, optimal crop yield increases are achieved when narrow windbreaks have dense to medium porosity, consisting of fast-growing and non-competitive trees species (Kort 1988). Several tall, long-lived species with deep root systems and similar growth should be planted.

Two primary factors that determine windbreak effectiveness in reduction of wind speed are the windbreak height and porosity. Windbreak height determines the horizontal extent of the sheltered area (Koh et al. 2014). According to Heisler and Dewalle (1988) upwind and downwind effects are usually assumed to be proportional to windbreak height, noted as $\mathrm{H}$ in formulas and models. Reductions of wind speed have been recorded as far as $50 \mathrm{H}$ to the leeward zone (Naegeli 1964; Monteith 1973) and reductions of about $20 \%$ may extend to about $25 \mathrm{H}$ from the windbreak (Naegeli 1946). The protected zone on the windward side is in the range of $2-5 \mathrm{H}$. On the leeward side the peak protected zone is usually between 6 and $10 \mathrm{H}$ and extends to about $15 \mathrm{H}$ downwind (Brandle et al. 2009). Most benefits occur within $10 \mathrm{H}$ on the leeward zone or between 0 and $3 \mathrm{H}$ on the windward side (Baldwin 1988; Cleugh et al. 2002; Helmers and Brandle 2005). This research agrees with Helmers and Brandle (2005), demonstrating the yield response for a field windbreak, which subtracts yield loss due to windbreak competition from the yield gain due to windbreak protection to estimate the net windbreak effect. In this study, we also consider that the potential yield of the windbreak footprint also needs to be subtracted, to estimate the total impact on yield from the windbreak (Fig. 1).

Previous research demonstrated that most yield increase due to windbreaks occur within $10 \mathrm{H}$ in the downwind zone, or within 0-3 H in the windward side (Grace 1977; Kort 1988; Baldwin 1988) The world data compilation done by Kort (1988) showed yield increases from $0.5-13 \mathrm{H}$ on the leeward side of the field. Sudmeyer and Scott (2002) reported that regardless of the season, crops in the downwind protected zone from 3 to 20 times the windbreak $\mathrm{H}$ presented an increase in yield of 16-30\% relative to the unprotected area beyond 30 times the $\mathrm{H}$ of the windbreak. It has generally been confirmed that maximum yield gains are usually found between 3 and $10 \mathrm{H}$ in the quiet zone, which is the zone immediately behind the windbreak (Cleugh 1998). Yield reductions can also occur, according to Stoeckeler (1962), with a potential negative impact for crops closer than $1.5 \mathrm{H}$ from the windbreak.

Crop yield reductions close to the vegetative barriers result from a combination of above-and below-ground competition between shelterbelts and crops (Brenner et al. 1993). According to Stoeckeler (1962) competition between tree and crop roots for soil moisture and shading is likely the primary cause for yield reductions adjacent to windbreaks. Other reasons for crop yield reductions include allelopathy, increased temperatures, and nutrient leaching after heavy snow accumulation (Kort 1988; Andrue et al. 2009). Greb and Black (1961) reported that moisture content of the area is a key factor that affects the competition between crops and windbreaks. Crop type is another factor to consider in the effect of a windbreak. In one study wheat (Triticum) and oats (Avena sativa) showed larger losses in the zone close to the barrier (Bates 1944). Other important reasons that explain crop yield increases in the protected zone are reduction in leaf abrasion, stripping and tearing of vegetable crops, and microclimate change (Cleugh 1998) due windbreak effect. Temperature and evapotranspiration rate have a positive influence over plants behind the windbreaks, suffering less moisture stress and leading to better growth due to less mid-day 
Fig. 1 Crop yield response for a field windbreak. Modified from Read (1964) and Helmers and Brandle (2005)

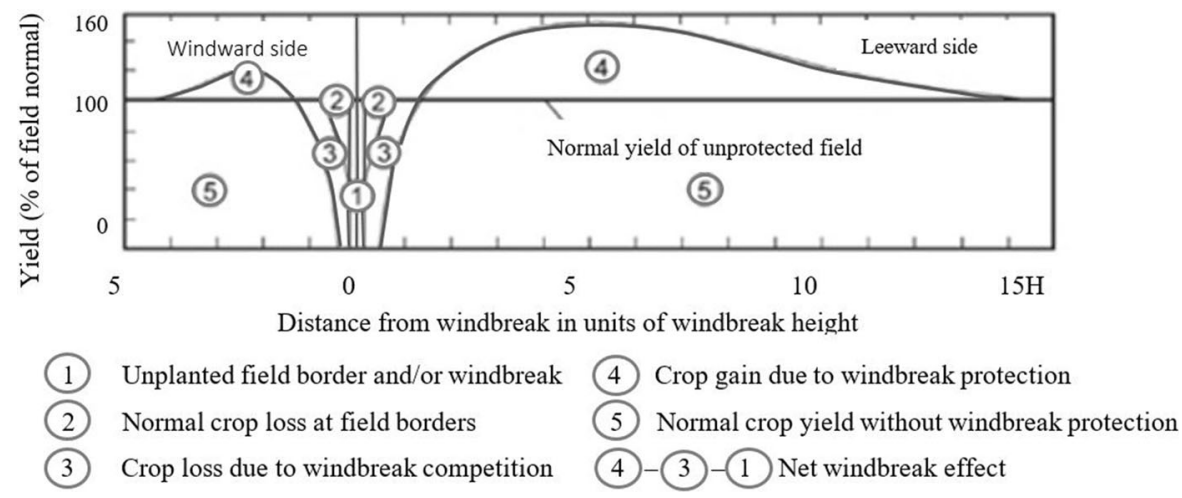

wilting and stomatal closure resulting in cessation of the photosynthetic activity (Andrue et al. 2009). The increase or decrease of evaporation rates depends on weather, soil conditions, and plant water status (Cleugh 1998).

To our knowledge, there are very few recent studies evaluating crop yield benefits of windbreaks. Additionally, most of the studies (Bates 1944; Stoeckeler 1962; Brandle et al. 1984) have used small plots or trials protected by windbreaks on research areas to record data, thus there can be issues of scale, comparing plot yields to entire fields. A small pilot study utilizing combine yield monitor data was conducted in Minnesota (Wyatt 2008). However, no reports could be found of geo-referenced crop yield monitor data being used in a windbreak study of this scale.

The main objective of this study was to develop a GIS approach using georeferenced combine-generated crop yield monitoring data to: (1) determine if windbreaks provide yield benefits for soybeans and wheat; and (2) assess if the yield increase was enough to compensate for the footprint of the windbreak.

\section{Materials and methods}

Study area

The area of study consisted of 23 non-irrigated crop fields located in Kansas and Nebraska. The fields were located in the north central part of Kansas in the following counties: Mitchell (1), Ottawa (1), Dickinson (10), Clay (3); and in south central Kansas in Stafford (1), Edwards (2), and Rice (2). Also, two farmers in Nebraska provided data from fields in Red
Willow (2) and Knox (1) counties. Fields were selected under the following criteria: long enough fields (length more than 30 times the height $(\mathrm{H})$ of the windbreak) or pairs of fields, one with a windbreak and the other without in order to compare the yield in the protected and un-protected zones. Only about $15 \%$ of the fields had the ideal adjacent protected and nonprotected fields for comparison. The rest of the fields had to use as unprotected control areas more than $30 \mathrm{H}$ downwind.

Selected fields had windbreaks with good structural features: height $(\mathrm{H})$, orientation, length, width, uniformity, and continuity according to literature guidelines (Brandle et al. 2000; Bates 1944). It is important to mention that most of the selected fields were long, with more than $80 \mathrm{H}$ length in units of windbreak height. In those fields, the unprotected control area was considered starting at $30 \mathrm{H}$ downwind, and this zone averaged more than two times larger than the area of the windbreak protected area $(20 \mathrm{H})$ in this study. Sudmeyer and Scott (2002) reported that crops in the downwind protected zone from 3 to 20 times the windbreak $\mathrm{H}$ have demonstrated an increase yield comparing it to the unprotected area from 30 times the $\mathrm{H}$ of the windbreak and beyond.

\section{Study promotion}

The first step was to identify farmers and landowners willing to share yield monitoring data from crop fields with and without windbreak protection. The research project was promoted for several years by K-State Research and Extension and the U.S. Department of Agriculture's Natural Resources Conservation Service (NRCS) in Kansas through state conferences and press releases. Most of the cooperators were obtained 
through presentations at the Kansas Agricultural Research and Technology Association (KARTA) annual meetings, with a few referrals from the NRCS offices and from an article published in the Furrow John Deere magazine titled "A Break for Higher Yields" (Reichenberger 2015). Study challenges were to access the data and securing cooperation of producers. Several farmers expressed reluctance to share personal yield data with government agencies. It took several visits (3 years in a row) to the KARTA annual meeting to gain the trust of several cooperators. More data could likely be collected if locally known personnel with farming backgrounds had direct contact and persistent outreach with landowners about the study.

\section{Data collection}

\section{Field windbreak general information}

Field measurements including on-the-ground landowner data, which consisted of field location, date, landowner name, crops grown, agricultural practices, and windbreak general measurements (tree species, average height, length, width, and optical density) were all collected through field visits in 2015-2016 winter and summer seasons. Data were recorded on a field data sheet. Average windbreak $\mathrm{H}$ and width were measured using terrestrial laser scanning (TLS) with a laser rangefinder as accomplished by (Moskal and Zheng 2011). Srinivasan et al. (2015) demonstrated that terrestrial laser scanning is an effective tool to measure tree level $\mathrm{H}$, crown width, and stem diameter. Windbreak field locations were identified in aerial photographs. Aerial photographs were obtained from the Kansas Data Access and Support Center (DASC 2017), the website Kansasgis.org, and from the Farm Service Agency (FSA) National Agriculture Imagery program (NAIP).

Most of the data were collected from producers in Kansas, with $>60 \%$ of the data collected from two farmers with multiple fields in the north central part of the state. All data were obtained from no-till fields.

\section{Crop yield data}

The key to this study is that several years of crop yield data already existed with farmers that have crop yield monitors installed on their equipment and have stored the information on their computers. According to Tilman et al. (2002) crop yield monitors are electronic devices that incorporate data from a yield sensor designed to measure crop yield in the field while harvesting. Also, in most cases, crop yield monitors are coupled with a Differential Global Positioning System (DGPS) to record crop yield data for virtually every point in a field relating the grain flow to yield with location (Nowatzki 2007). Summaries are downloaded via the storage devices to the famer's computer and opened in spreadsheets for further data analysis and record keeping.

Generally, computer software associated with crop yield monitors has a data export function to extract data for each field. Yield data were exported as a point shapefile which is a format with four file extensions: shp., dbf., shx., and prj. In most cases these monitor data were collected on a portable hard drive from the producer's computer during the field visits or flash drives were mailed directly to the authors.

The crop field/year term in this study refers to a particular crop (soybean or wheat), harvested in a particular field for a specific year. A total of 264 crop field/years (139 soybean and 125 wheat) were collected across nine counties in two states (Kansas and Nebraska) from nine farmers. The yield data were collected from 18 growing seasons (1998-2015) which represented a total of 264 crop field/years. In general, rainfall was very variable during growing seasons under study, with more dryer than wetter and few seasons with normal rainfall (Lawrimore et al. 2011; ACIS 2017). In Kansas, data were collected from the counties Mitchell (6 crop/years), Stafford (2 crop/years), Edwards (13 crop/years), Ottawa (20 crop/years), Rice (20 crop/years), Dickinson (96 crop/ years), and Clay (98 crop/years). Nebraska counties included Red Willow (7 crop/years) and Knox ( 2 crop/ years). The two largest data sources from Dickinson and Clay counties in Kansas were recruited from the KARTA annual meeting in 2016. These two ownerships provided data from 13 fields, 194 crop/years, thus accounting for $73 \%$ of the total data in this report.

Crop yield monitor data information, along with location data, are essential to analyze the effects of field windbreaks on crop yield through the creation of yield monitor maps (data projection) and data extraction. 
Data analysis: ArcGIS

ArcGIS $10.3 .1^{\odot}$ (ESRI, Redlands, CA) was used to clean, project, and extract monitor yield data. Data and aerial photos were added in ArcGIS 10.3.1 ${ }^{\circledR}$ (ESRI 2011) to clean the crop yield data using a standard protocol adapted from Sudduth and Drummond (2007) and Cordoba et al. (2016). This process was done by removing zeros and outlier values greater than \pm 3 standard deviation units from the mean, which originated because a number of yield monitor data errors can be associated with each data file generated within a field. These are errors that occur when the harvest equipment passes more than one time through the same point of the field for turns and begins harvesting the next swath at the beginning of the previous cut. At the end of the line the combine header moves from down position during the completion of a pass to the up position, this lag can generate more errors in the data which mostly occur at the field edges (Arslan and Colvin 2002a).

After cleaning, sorting, and selecting data to compare, a total of $101 \mathrm{crop} / y e a r s$ were available for data analysis. Kansas counties included Mitchell (6 crop/years), Stafford (2 crop/years), Edwards (3 crop/ years), Ottawa (6 crop/years), Rice (8 crop/years), Dickinson (38 crop/years), and Clay (35 crop/years). Nebraska counties were Red Willow (1 crop/years) and Knox ( 2 crop/years). Total analyzed crop/years by crops were: 57 soybeans/years, and 44 wheat/years. The rest of the data could not be used for this study because the fields were not long enough to have protected and un-protected zones, unpaired small fields (just with protected or un-protected areas), windbreaks were not uniform or not in good condition (many gaps). There were a few yield monitor data files that had many errors and zeros in the files which made them unusable. According to Arslan and Colvin (2002b) inaccurate yield monitor data is usually due to lack of calibration, improper installation, operation, and inspection of the yield monitor sensors.

After the data were cleaned, selection of data to analyze per field was done through the select features option. Creation of strips or bands along the study field was the next step. This was achieved using the fishnet tool where the strip width was equal to the windbreak's average height as measured in the field. Afterwards, a spatial join was run in order to join the bands with the yield data points calculating an average of all the yield points that fall in each band. Creation of a choropleth map was done using the layer properties (Fig. 2). Finally, the data were extracted from ArcGIS to an Excel spreadsheet by an export function.

\section{Statistical analysis}

The data were analyzed using two-sample t-tests to compare group means between protected and unprotected fields defined by the unique combination of field name, year and season with PROC TTEST in Statistical Analysis Software (SAS) 9.3 (SAS Institute Inc; Cary N.C). In order to decide which $t$ test to use, a hypothesis test of equal population variances was conducted prior to conducting the t-test for means. When variances were unequal the Satterthwaite test was applied, if equal variance existed then a Pooled test was used. There is evidence that the yield in a protected field is different from yield in an unprotected field if $P<0.05$.

\section{Results and discussion}

Do windbreaks improve yields of modern crops?

A comparison between relative yield from the protected and unprotected areas, showed that for 60 out of 101 crop/years yields were significantly different $(P<0.05)$. Based on the analysis, 38 out of $60 \mathrm{crop}$ field/years showed significant yield increases, indicating that the average yield in the protected area was greater than in the unprotected area. The rest of the significantly different crop field/years (22) showed significant yield decreases, indicating that the average yield in the protected area (including the area planted to the windbreak and competition zone) was less than the average yield in the unprotected area. According to Greb and Black (1961) in drier regions of the Great Plains, competitive yield decreases were more predominant due to moisture competition. The crop/years analyzed that were not significantly different (41 out of $101 \mathrm{crop} / \mathrm{years}$ ), can be assumed to have neither significant yield increases or decreases in the protected and unprotected area. Table 1 shows the yield increase and decrease frequency percentage by crop from 60 significantly different crop field/years and the average size of the fields in hectares, respectively. 
Fig. 2 Wheat choropleth yield map $\left(\mathrm{kg} \mathrm{ha}^{-1}\right)$ in Mitchell County, KS, 2011
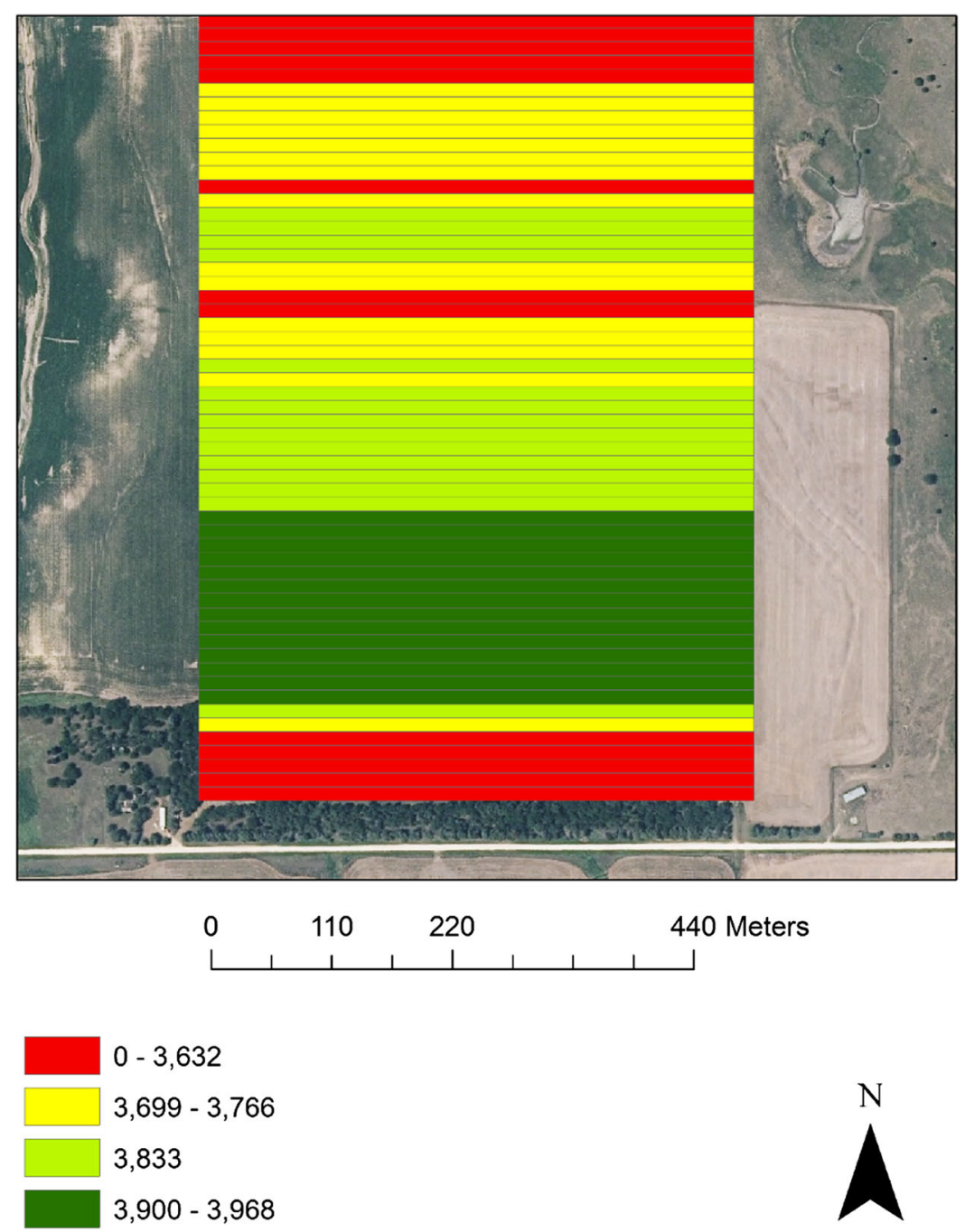

Table 1 Significant differences (frequency \%) by crop for both yield increase and decreases due to windbreak effect, number of significantly different crop field/years and the number of crop field/years analyzed

\begin{tabular}{lllllll}
\hline Crop & $\begin{array}{l}\text { Yield } \\
\text { increase }(\%)\end{array}$ & $\begin{array}{l}\text { Yield } \\
\text { decrease }(\%)\end{array}$ & $\begin{array}{l}\text { Significantly } \\
\text { different crop } \\
\text { field/years }\end{array}$ & $\begin{array}{l}\text { Total of crop } \\
\text { field/years } \\
\text { analyzed }\end{array}$ & $\begin{array}{l}\text { Field avg. } \\
\text { size increase } \\
\text { (ha) }\end{array}$ & $\begin{array}{l}\text { Field avg. } \\
\text { size decrease } \\
\text { (ha) }\end{array}$ \\
\hline Soybeans & 46 & 23 & 38 & 57 & 28.7 & 25.3 \\
Wheat & 30 & 20 & 22 & 44 & 28.7 & 27.5 \\
Total & & 60 & 101 & & \\
\hline
\end{tabular}

Field average size (hectares) for yield increase and decrease is shown for each crop, respectively

Soybeans were the most responsive crop to windbreak effect with a $46 \%$ yield increase frequency followed by wheat with a $30 \%$ yield increase frequency due to windbreak effect. According to compilation of data from 50-worldwide studies from 1934 to 1984 reported by Kort (1988), wheat was also 
reported as one of the highly responsive crops to windbreak protection followed by soybeans. As previously mentioned, all data were obtained from no-till fields, where the crop-soil moisture relations may be different from tilled fields.

Overall, soybeans had a bigger sample size than wheat because most of the data were collected from the leading soybean production counties in Kansas (USDA-NASS 2017), where the yield increase was enhanced by the windbreak effect.

\section{Average yield increases due to windbreak effect}

Figure 3 shows the average crop yield increase percentage due to the windbreak effect by crop for $38 \mathrm{crop} /$ years that had significantly increased yields and the average size of the protected area $(1-20 \mathrm{H})$ in hectares. The summer crop, soybeans (16\%) had a greater yield increases than the winter crop wheat (10\%) due to the windbreak effect. Kort (1988) also reported less yield increase in winter wheat (23\%) out of 131 crop/years and spring wheat $(8 \%)$ out of 190 crop/years, with many authors reporting that sheltered wheat yield decreased due to several reasons. Brandle et al. (1984) reported that windbreaks may enhance fungal diseases in winter wheat, and yields were reduced by wheat scab, but in most cases this is not very common (Brandle et al. 2009); Bates (1944) mentioned that wheat showed higher yield decreases due to windbreak competition while Stoeckeler (1965) classified wheat and corn as a low-response crops to windbreak effect.

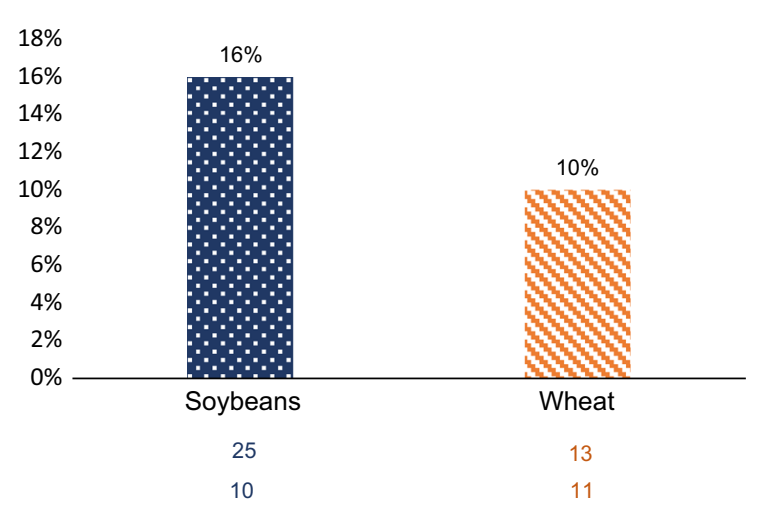

Fig. 3 Mean yield increase (\%). Number of crop field/years analyzed and protected area $(1-20 \mathrm{H})$ average size (hectares) is shown for each crop, respectively
In terms of absolute yield amounts, the average increase was $283 \mathrm{~kg} \mathrm{ha}^{-1}$ for soybean and $319 \mathrm{~kg} \mathrm{ha}^{-1}$ for wheat. It is important to mention that these values are just estimates, as yield monitors were not calibrated during the study period, thus only relative differences within a field were compared.

According to Kort (1988) efficacy of the windbreak protection is related to stage of crop development. Most windbreaks in the study were primarily composed of deciduous trees with only a few with evergreen trees. Beetz (2002) and Gonzales (2015) agreed that using all deciduous trees in windbreaks are not recommended for year-round protection, even if planted in multiple rows because they are less effective during the winter due to leaf loss. Therefore, deciduous trees do not provide protection at the critical stage for wheat crop development. This could be a factor that may have led to less yield increases in wheat due to the windbreak effect.

Significant positive windbreak effects on yield were seen across fields, counties, and in both states. In Kansas, counties and crop/years that showed significant differences in yield increase were: Stafford (one/ one field, one/2 crop-years), Mitchell (one/one field, one/6 crop-years), Ottawa (one/two fields, three/6 crop-years), Rice (one/two fields, four/8 crop-years), Clay (two/three fields, 12/35 crop-years), and Dickinson (six/eight fields, 16/38 crop-years). In Nebraska, Knox County was one/one field, one/2 crop-years. According to Stoeckeler (1962) climate is a factor and the geographic location influences the crop response to the windbreak effect. In regions where more precipitation falls as snow, such as in North Dakota and South Dakota, yield increase may be greater than places like Kansas and Nebraska. Brandle et al. (2009) reported an average $23 \%$ yield increase for winter wheat analyzing 131 field years of data from a review of studies (Kort 1988; Baldwin 1988; Brandle et al. 1992).

In terms of maximum rooting depth (m), according to Canadell et al. (1996), soybean rooting system is slightly deeper at $1.8 \mathrm{~m}$ (Mayaki et al. 1976) compared to wheat with $1.4 \mathrm{~m}$ (Chaudhuri et al. 1990) in Kansas and wheat in Nebraska with $1.5 \mathrm{~m}$ (Weaver and Bruner 1926). Perhaps, soybean roots share less of the same rooting zones with close trees than wheat does. According to Greb and Black (1961) and George (1971), this could be a factor of less yield reduction for soybeans due to windbreak competition for moisture, 
and any yield decreases could be related to nutrients leaching in greater snowfall regions. An analysis of yield increases summarized from worldwide studies (Kort 1988; Baldwin 1988; Brandle et al. 1992) by Brandle et al. (2009) indicated significant yield increases for soybeans of $15 \%$ in 17 field years analyzed.

The precipitation pattern in the Great Plains varies along a gradient that goes from much drier lands in the west to wetter ones in the east (Kunkel et al. 2013). Most of the study fields were located in moderately dry regions, which could be a reason for fewer significantly different yield increases in this study. Stoeckeler (1962) mentioned that according to snowfall differences, greater yield increases due to windbreak protection were found in the northern Great Plains states than in Kansas and Nebraska.

Another reason that may have led to fewer significant yield increases due to the windbreak effect is that most of the study windbreaks were not in the best condition due to lack of maintenance practices and suboptimal design. Kort (1988) concluded that possible factors to enhance crop yield increases are good windbreak design, suitable species selection and careful maintenance practices like renovation, trimming, root-plowing, and weed control. Currently, windbreak removal in Kansas has increased due to many reasons such as farmers adopting no-till systems as a conservation practice in order to reduce soil erosion, installing large irrigation systems, or for an easier maneuvering of ever-larger equipment (Barden, personal communication 2017).

Is the yield increase enough to compensate for the footprint of the windbreak?

Considering the 38 crop/years that demonstrated significantly different yield increases due to the windbreak effect, several calculations were made in order to assess if the yield increase is enough to compensate for the land taken out of production (the footprint of the windbreak). In order to answer this question, the yield increase due to windbreak effect was compared with the projected yield lost within the footprint of the windbreak. The projected lost yield was calculated from yields observed in the unprotected zone field edges, equivalent to the width of the windbreak. If the windbreak was not present, then the yield of that area should be equivalent to the unprotected zone yield from the edges of the field. This average yield was then multiplied by the area of windbreak footprint.

Results of calculations showed a total of 20 out of $38(53 \%)$ of crop-years that showed a significant yield increase also compensated for lost yield in the windbreak footprint. Figure 4 shows that there is a yield compensation $71 \%$ of the time for north windbreaks and Fig. 5 shows that there is a yield compensation $38 \%$ of the time for south windbreaks.

The variable windbreak effect due to width and location may be confounded by the fact that the average width of north windbreaks was 11.3 meters, while south windbreaks had an average width of 24.4 meters. Therefore, as Kort (1988), Josiah and Wilson (1996), and Brandle et al. (2004) mentioned narrow windbreaks (one or two rows) are better than wider windbreaks when considering total yield and whether the yield increase compensates for the footprint of the windbreak. The wider shelterbelts take more land out of production. Stoeckeler (1962) recommended that field windbreaks should occupy $<5 \%$ of the land area for the yield to compensate for the footprint of the windbreak and to provide maximum crop protection.

\section{Conclusions}

Following the 1930s Dust Bowl in the U.S. Great Plains, windbreaks were established with the original purpose of reducing wind erosion. According to

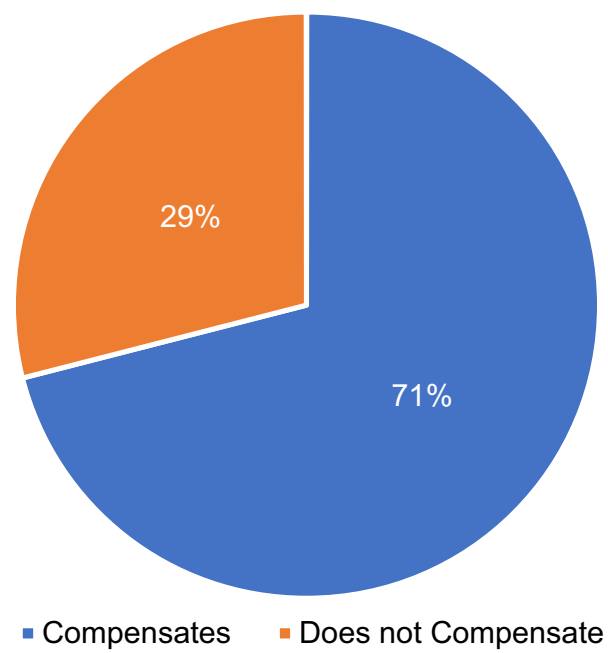

Fig. 4 North windbreak compensation due to windbreak effect 


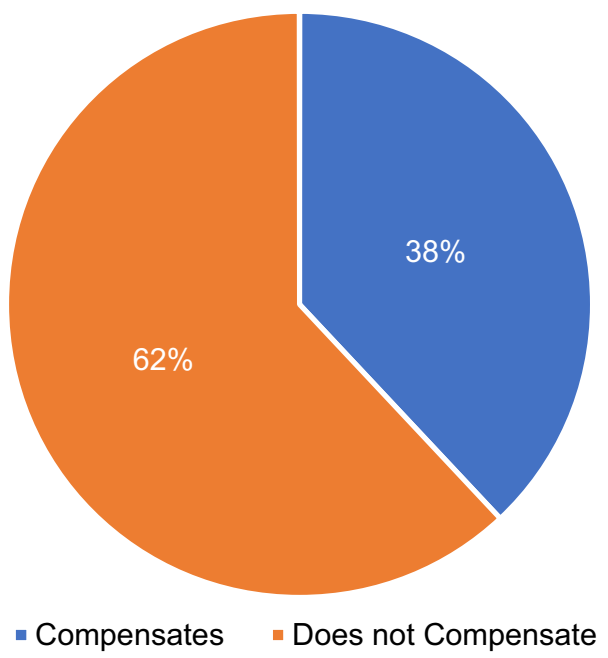

Fig. 5 South windbreak compensation due to windbreak effect

several studies, windbreaks accomplished their purpose successfully and at the same time have been shown to improve crop yields. Based on the proposed goals for this study, to determine if windbreaks improve yields of soybeans and wheat, it can be concluded that windbreaks provided crop yield benefits. Soybeans presented the most positive response to windbreak effect showing a yield increase $46 \%$ of the time, with a $16 \%$ average yield increase; followed by wheat with a $30 \%$ of the time, with a $10 \%$ average yield increase. As to the second goal of this study, if yield increase is enough to compensate for the footprint of the windbreak, it can be concluded that yield increase from north and narrow windbreaks (71\%) compensated for the footprint of the windbreak more often than south and wider windbreaks (38\%).

For future studies, it is recommended further data collection with different windbreak widths in different counties and states in order to broaden the tillage regime, soil types, windbreaks, and climate represented. The methods documented in this report can be used to collect more combine crop yield monitoring data in the future. This would deepen our understanding of the interaction between windbreaks and crop yield and perhaps effect their future role as a conservation practice in the Great Plains.

Acknowledgements Funds for this study were provided by the National Agroforestry Center, Kansas Forest Service, and the United States Department of Agriculture Forest Service. This is a contribution no. 18-233-J from the Kansas Agricultural Experiment Station.
Open Access This article is distributed under the terms of the Creative Commons Attribution 4.0 International License (http:// creativecommons.org/licenses/by/4.0/), which permits unrestricted use, distribution, and reproduction in any medium, provided you give appropriate credit to the original author(s) and the source, provide a link to the Creative Commons license, and indicate if changes were made.

\section{References}

Andrue MG, Tamang B, Friedman MH, Rockwood DL (2009) The benefits of windbreaks for Florida growers. FOR192 University of Florida Institute of Food and Agricultural Sciences. http://edis.ifas.ufl.edu/fr253. Accessed 13 March 2017

Applied Climate Information System (ACIS) (2017) hosted by NOAA Regional Climate Centers (RCCs). http://scacis. rcc-acis.org/. Accessed 23 January 2017

Arslan S, Colvin TS (2002a) An evaluation of the response of yield monitors and combines to varying yields. Precis Agric 3(2):107-122

Arslan S, Colvin TS (2002b) Grain yield mapping: yield sensing, yield reconstruction, and errors. Precis Agric 3(2):135-154

Baldwin CS (1988) The influence of field windbreaks on vegetable and specialty crops. Agr Ecosyst Environ 22:191-203

Bates CG (1944) The windbreak as a farm asset. USDA Farmers Bulletin No. 1405

Beetz AE (2002) Agroforestry: overview. ATTRA (Appropriate Technology Transfer for Rural Areas). http://www. rareplanet.org/sites/rareplanet.org/files/agrofor.pdf. Accessed 16 Feb 2017

Brandle JR, Johnson BB, Dearmont DD (1984) Windbreak economics: the case of winter wheat production in eastern Nebraska. J Soil Water Conserv 39:339-343

Brandle JR, Johnson BB, Akeson T (1992) Field windbreaks: are they economical? J Prod Agric 5(3):393-398

Brandle JR, Hodges L, Wight B (2000) Windbreak practices. In: Garrett HE, Rietveld WJ, Fisher RF (eds) North American Agroforestry: an integrated science and practice. Am Soc Agron Inc, Madison, pp 79-118

Brandle JR, Hodges L, Zhou XH (2004) Windbreaks in North American agricultural systems. Agroforest Syst 61:65-78

Brandle JR, Hodges L, Tyndall J, Sudmeyer RA (2009) Windbreak practices. In: Garrett HE (ed) North American Agroforestry: an integrated science and practice, 2nd edn. Am Soc Agron, Madison, pp 85-88

Brenner AJ, van den Beldt RJ, Jarvis PG (1993) Tree-crop interface competition in a semi-arid Sahelian windbreak. In: 4th international symposium on windbreaks and agroforestry, 26-30 July, 1993, Viborg

Canadell J, Jackson RB, Ehleringer JB, Mooney HA, Sala OE, Schulze ED (1996) Maximum rooting depth of vegetation types at the global scale. Oecologia 108(4):583-595

Chaudhuri UN, Kirkham MB, Kanemasu ET (1990) Root growth of winter wheat under elevated carbon dioxide and drought. Crop Sci 30:853-857 
Cleugh H (1998) Effects of windbreaks on airflow, microclimates and crop yields. Agrofor Syst 41(1):55-84

Cleugh H, Prinsley R, Bird P, Brooks S, Carberry P, Crawford M et al (2002) The Australian national windbreaks program: overview and summary of results. Anim Prod Sci 42(6):649-664

Cordoba MA, Bruno CI, Costa JL, Peralta NR, Balzarini MG (2016) Protocol for multivariate homogeneous zone delineation in precision agriculture. Biosyst Eng 143:95-107

Croker T (1991) The Great Plains shelterbelt. Artistic Printers, Greenville

DASC (2017) Kansas data access \& support center. https:// www.kansasgis.org/index.cfm. Accessed 17 April 2017

Droze WH (1977) Trees, prairies, and people: a history of tree planting in the plain states. USDA Forest Service and Texas Woman's University Press, Denton, p 331

ESRI (2011) ArcGIS desktop: release 10.3.1. Environmental Systems Research Institute, Redlands

George EJ (1971) Effect of tree windbreaks and slat barriers on wind velocity and crop yields. USDA Agricultural Research Service. Prod. Res. Rep. No.121. Washington

Ghimire K, Dulin MW, Atchison RL, Gooding DG, Hutchinson JS (2014) Identification of windbreaks in Kansas using object-based image analysis, GIS techniques and field survey. Agrofor Syst 88(5):865-875

Gonzales HB (2015) Aerodynamics of wind erosion and particle collection through vegetative controls. Dissertation, Kansas State University

Grace J (1977) Plant response to wind. Academic Press, London

Greb BW, Black AL (1961) Effects of windbreak plantings on adjacent crops. J Soil Water Conserv 16:223-227

Hansen ZK, Libecap GD (2004) Small farms, externalities, and the dust bowl of the 1930s. J Polit Econ 112(3):665-694

Heisler GM, Dewalle DR (1988) Effects of windbreak structure on wind flow. Agr Ecosyst Environ 22:41-69

Helmers GA, Brandle J (2005) Optimum windbreak spacing in Great Plains agriculture. Great Plains Res 15:179-198

Josiah SJ, Wilson JS (1996) G96-1304 Windbreak design (revised March 2004). Historical materials from University of Nebraska-Lincoln Extension, vol 849. https:// digitalcommons.unl.edu/cgi/viewcontent.cgi?referer= https://scholar.google.com/\&httpsredir=1\&article= $1847 \&$ context=extensionhist. Accessed 27 April 2017

Koh I, Park C, Kang W, Lee D (2014) Seasonal effectiveness of a Korean traditional deciduous windbreak in reducing wind speed. J Ecol Environ 37(2):91-97

Kort J (1988) Benefits of windbreaks to field and forage crops. Agr Ecosyst Environ 22(23):165-190

Kunkel KE, Stevens LE, Stevens SE, Sun L, Janssen E, Wuebbles D et al (2013) Regional climate trends and scenarios for the U.S. Natl Clim Assess Part 3:142-143

Lawrimore JH, Menne MJ, Gleason BE, Williams CN, Wuertz DB, Vose RS, Rennie J (2011) An overview of the global historical climatology network monthly mean temperature data set, version 3. J Geophys Res 116:D19121. https://doi. org/10.1029/2011JD016187

Mayaki JWC, Teare ID, Stone LR (1976) Top and root growth of irrigated and nonirrigated soybeans. Crop Sci 16:92-94

Monteith JL (1973) Principles of environmental physics. Elsevier, New York
Moser WK, Hansen MH, Atchison RL, Brand GJ, Butler BJ, Crocker SJ, Wodall CW, et al (2008) Kansas forests 2005. USDA, Forest Service, Northern Research Station. https:// www.nrs.fs.fed.us/pubs/rb/rb_nrs26.pdf. Accessed 22 Jan 2017

Moskal LM, Zheng G (2011) Retrieving forest inventory variables with terrestrial laser scanning (TLS) in urban heterogeneous forest. Remote Sens 4(1):1-20

Naegeli W (1946) Further investigations of wind conditions in the range of shelterbelts. Mitt Schweiz Anst Forstl Versuchswes 24:660-737

Naegeli W (1964) On the most favorable shelterbelt spacing. Scott. For 18:4-15

Nowatzki J (2007) Get accurate information from combine yield monitors. News NDSU Communications. https://www.ag. ndsu.edu/news/newsreleases/2007/aug-16-2007/getaccurate-information-from-combine-yield-monitors. Accessed 6 April 2017

Read RA (1964) Tree windbreaks for the central great plains. Agriculture Handbook 250. Department of Agriculture Forest Service. Washington

Reichenberger L (2015) A break for higher yield. John Deere's The Furrow Magazine. https://www.nrcs.usda.gov/wps/ PA_NRCSConsumption/download?cid= stelprdb1269469\&ext=pdf/. Accessed 6 June 2016

SAS Institute Inc, (2002-2004) SAS 9.3 help and documentation. SAS Institute Inc., Cary, NC

Srinivasan S, Srinivasan S, Popescu SC, Eriksson M, Sheridan RD, Ku N (2015) Terrestrial laser scanning as an effective tool to retrieve tree level height, crown width, and stem diameter. Remote Sens 7(2):1877

Stoeckeler JH (1962) Shelterbelt Influence on Great Plains Field Environment and Crops. USDA Forest Service, Production Research Project No. 62

Stoeckeler JH (1965) The design of shelterbelts in relation to crop yield improvement. World Crops 17:27-32

Sudduth KA, Drummond ST (2007) Yield editor. Agron J 99:1471-1482

Sudmeyer R, Scott P (2002) Characterization of a windbreak system on the south coast of western australia. 1. microclimate and wind erosion. Animal Production. Science 42(6):703-715

Tamang B, Andreu MG, Friedman MH, Rockwood DL (2015) Windbreak designs and planting for Florida agricultural fields. FOR227. University of Florida Institute of Food and Agricultural Sciences. http://edis.ifas.ufl.edu/. Accessed 18 March 2017

Tilman D, Cassman KG, Matson PA, Naylor R, Polasky S (2002) Agricultural sustainability and intensive production practices. Nature 418(6898):671-677

USDA-NASS (2017) Kansas production statistics. https://www. nass.usda.gov/Charts_and_Maps/Crops_County/. Accessed 15 April 2017

Weaver JE, Bruner WE (1926) Root development of field crops. McGraw-Hill, New York

Wyatt GJ (2008) Field Windbreak/Living Snow Fence Crop Yield Assessment. Greenbook: Cropping Systems and Soil Fertility. Minnesota Department of Agriculture. http:// www.mda.state.mn.us/news/publications/protecting/ sustainable/greenbook2008/cssf-windbreaks.pdf. Accessed 2 June 2018 